\title{
Diet Changes Lives
}

\section{Tresa Anto*}

Vice Principal, Jubilee Mission College of Nursing, Kerala, India

Submission: May 09, 2018; Published: May 22, 2018

*Corresponding author: Tresa Anto, Vice Principal, Jubilee Mission College of Nursing, Kachery, Thrissure-5, Kerala, Email: srtresaanto@gmail.com

\section{Introduction}

Food is the basic necessity of man. It is a mixture of different nutrients such as carbohydrate, protein, fat, vitamins and minerals. These nutrients are essential for growth, development and maintenance of good health throughout life. Charak Samhita supports the use of nutritious food. The important factor which leads for the healthy growing of individuals is nutritious diet. A Diet without adequate nutrients leads to different types of health problems. Charka states that small quantity of food which is easily digestible and good nutritious food items may not be needed for meeting the energy requirement after attaining the satity level.

\section{If You Care You Get Credit}

The food items promote harmony among the body system and helps in retaining equanimity in the body systems. Fruits and vegetables are protective foods which provide vitamins and minerals required for growth and maintenance of health. Roots and tubers provide energy. Vegetables are low in fat and can be used liberally in low calorie diets for weight reduction. Nuts are a rich source of protein and fat and a good source of B -Vitamin and antioxidant vitamin E. They are a concentrated source of energy. The white flesh of coconut is rich in calories though not a very good source of protein. Almonds are an excellent source of vitamin E, an antioxidant. Coriander seed are recommended in hypertension. Fenugreek seeds reduces blood sugar, GarlicLowers blood cholesterol and blood pressure levels, Onion lower blood glucose levels and blood cholesterol levels.

Tender Coconut Water rich in Potassium, ascorbic acid and many vitamins of the B group are present in coconut water. Apart from this, the water also contains traces of calcium, phosphorus and iron. Germinated pulses reduces the anti -nutritional and toxic factor in pulses. Dormant enzymes get activated and digestibility and availability of nutrients is improved. Minerals like calcium, zinc and iron are released from bound form. Sprouted pulses can be eaten raw, since germination improves taste and texture sprouted pulses can be added to salads. continuous excessive boiling leads to damage in the structure and texture of food. Loss the heat labile nutrients such as B and C vitamins if the water is discarded. Water soluble nutrients may be lost into the water. Roasting denatures proteins reducing their availability. Fried foods are not easily digested. Repeated use of heated oils will have ill effects on health. The items which are difficult to digest should be avoided. Extra food can harm the body [1].

\section{Life Saving Tips}

Diet control has been a mainstay of the therapeutic regime used to treat diabetes mellitus. It is generally recognized that overweight diabetic patients on oral anti-diabetic agents can sometimes have their oral agents discontinued if they lose weight and adhere closely to an anti-diabetic diet [2]. Enzymes are the power of life. They are living forces that conduct and direct every activity in our body. Enzymes digest or breakdown raw foods More and more research suggests eating high enzyme food helps digestion. Eating an enzyme rich diet is thought to increase vitality and slow the aging process. enzymes can even help repair our DNA and RNA. One of the keys for easy weight loss is through the action of enzymes for example lipase, a fat splitting enzyme, is found in raw foods. Lipase helps body in digestion and fat burning for energy. Protease is another enzyme for keeping a healthy body. protease split up protein into their component amino acid building blocks and help eliminate toxins. enzymes are heat sensitive and destroyed at temperature above 118 degrees [1]. Ayurveda explains three types of 'Ahar' or food habits 'Satwik', 'Rajasik' and 'Tamasik'. Rishis preferred 'Satwik ahar' which consist of 'Kanda', 'Moola', 'Phala'(vegetables and fruits) and their life span was hundred years. In today's circumstances, this consists of a 1300 caloric diet with high fiber, little amount of fat, small amount of sodium, moderately high potassium \& minerals and abundance of antioxidants. This type of food gives the least oxidative stress. Extreme level of oxidative stress is the main seen in common health disorders and ageing process [3]

\section{Discussion}

A comparative study between the individuals who take raw diet for many years and those who take mixed diet The vegetable diet contains more of unsaturated and polysaturated and low saturated fatty acids. The proportion of n-3 fatty acids to $n-6$ fatty acids was only about half of the group than who took mixed diet. The study findings show, vegetarian food has less effect on the ratio of oleic and arachiedonic acid where, the level of n-3 fatty acids are very less with extended intake of high linoleic and oleic 
acid components of the food [4]. The biochemical interaction of living food among twenty females in Finnish. This was conducted by survey method. Vitamin C, E and beta-carotene levels were compared with control subjects. The vegetarian raw food group had elevated vitamin C, E, copper, beta-carotene and decreased intake of selenium than the control group. Their intake was parallel with recommended nutrition intake of US. Vitamin C $305 \%$, Vitamin A $247 \%$, vitamin C 313\%, copper $120 \%$, selenium $49 \%$. This reveals that vegetarian raw food supplements more antioxidants than the non-vegetarian subjects. Raw food is better in providing antioxidant than cooked diet [5].

\section{Conclusion}

Our diet has a direct bearing on our health and almost all illness are related to our diet. Researchers suggest that raw diet is best for controlling diseases supported with his result that the individuals who have been practicing the raw foods diet showed consistent improvement in physiological and psychological parameters [6]. Also reported that the effect of increased amount of uncooked vegetables and fruits showed low total cholesterol and triglyceride concentrations. observations support that raw diet is best for diabetes management [6].

\section{References}

1. Gopalan C, Rama Sastri BV, Balasubramanian SC (1989) Nutritive Value of Indian Foods, National Institute of Nutrition, ICMR, Hyderabad, India.

2. Douglass MD, John M (1975) Raw diet and Insulin Requirements. Ann Intern Med 82(1): 61-62.

3. Lele RD (2012) Ancient Indian insights and modern discoveries in nutrition, exercise and weight control. Association of the Physicians of India 60: 30-36.

4. Agren J, Tormala M, Nenonen M, Hanninen O (1995) Fatty acid composition of erythrocyte, platelet, and serum lipids in strict vegans. Lipids 30(4): 365-369.

5. Zajic, Lenkaj (2006) Raw food diet study, an investigation of over 500 people, who have eaten a raw food diet for over 2 years.

6. Koebnick Corinna, Garcia (2005) Long-Term Consumption of a Raw Food Diet Is Associated with Favourable Serum LDL Cholesterol and Triglycerides but Also with Elevated Plasma Homocysteine and Low Serum HDL Cholesterol in Human .The American Society for Nutritional Sciences 135: 2372-2378.

\section{Your next submission with Juniper Publishers will reach you the below assets}

- Quality Editorial service

- Swift Peer Review

- Reprints availability

- E-prints Service

- Manuscript Podcast for convenient understanding

- Global attainment for your research

- Manuscript accessibility in different formats

( Pdf, E-pub, Full Text, Audio)

- Unceasing customer service

Track the below URL for one-step submission https://juniperpublishers.com/online-submission.php 